\title{
ОЛЕКСАНДР КОНИСЬКИЙ - ПЕРЕКЛАДАЧ МАЛОЇ ПРОЗИ ЕЛІЗИ ОЖЕШКО: ЯК В УКРАЇНСЬКОМУ ЛІТЕРАТУРОЗНАВСТВІ О. КОНИСЬКОМУ ПРИПИСАЛИ АВТОРСТВО ТВОРУ ПОЛЬСЬКОЇ ПИСЬМЕННИЦІ
}

\author{
Ірина Спатар
}

Кандидат філологічних наук, доцент,

Кафедра світової літератури і порівняльного літературознавства,

Прикарпатський національний університет імені Василя Стефаника» (УКРАЇНА),

76018 м. Івано-Франківськ, вул. Шевченка, 57,

e-mail: iryna.spatar@pnu.edu.ua

\section{PЕФЕРАТ}

Mema - охарактеризувати переклади малої прози Е. Ожешко, здійснені О. Кониським, визначити передумови їхної появи на шпальтах українських часописів, довести, що в українському літературознавстві другої половини XX - початку XXI століття авторство однієї з новел польської письменниці помилково приписують О. Кониському. Дослідницька методика. У процесі дослідження застосовано такі методи, як: історико-літературний, біографічний, типологічний, контекстуальний. Результати. У статті наголошено, що О. Кониський один з найактивніших адептів національної ідеї другої половини XIX століття своєю багатогранною діяльністю лобіював інтереси народу, освітньо-культурне відродження розділеної країни, територіальне, ментальне і світоглядне воз'єднання українців Галичини i Наддніпрянщини. Він безпосередньо впливав на формування культурно-естетичних і світоглядних засад, що сприяли розвиткові української освіти, науки, літератури. Одним із шляхів націєтворення О. Кониський вважав утвердження національної мови, тому його художня творчість і переклади творів 3 російської та польської мов мали не лише естетичні, а й україноцентричні цілі. Наукова новизна. Визначено, що одна 3 новел Е. Ожешко, перекладена О.Кониським, у сучасному українському літературознавстві помилково окреслена не як переклад, а твір О. Кониського. Практичне значення. Основні результати дослідження можуть бути використані при подальшому вивченні польського та українського літературних процесів другої половини XIX - початку XX століття, а також літературної й перекладацької діяльності. О. Кониського.

Ключові слова: переклад, новела, національна ідея, листування, мала проза.

\section{OLEKSANDR KONYSKY - TRANSLATOR OF ELIZA ORZESZKOWA'S SMALL PROSE: HOW IN UKRAINIAN LITERARY CRITICISM THE AUTHORSHIP OVER THE POLISH WRITER'S WORK WAS ATTRIBUTED TO O. KONYSKY}

\author{
Iryna Spatar \\ $\mathrm{Ph}$. D. in Philology, Lecturer, \\ Department of World Literature and Comparative Literary Criticism, \\ Vasyl Stefanyk Precarpathian National University (UKRAINE), \\ 76018, Ivano-Frankivsk, 57, Shevchenko str., \\ e-mail: irynaspatar@ukr.net
}

\section{ABSTRACT}

The aim is to characterize the translations of E. Orzeszkowa's small prose by O. Konysky, to determine the conditions for their appearance on the front pages of Ukrainian journals, to prove that the authorship of one of the novels by the Polish writer is mistakenly attributed to Ukrainian writer in Ukrainian literary criticism of the second half of the $20^{\text {th }}$ - begining of the $21^{\text {st }}$ century. Methodology. In the process of the study the following 
methods were applied: historical and literary, biographical, typological and contextual. Results. The article emphasized that O. Konysky, being one of the most active adherents of the national idea of the second half of the $19^{\text {th }}$ century, lobbied the interests of the people, the educational and cultural revival of the divided country, the territorial, mental and ideological reunification of the Ukrainians of Halychyna and Naddnipryanshchyna (Dnieper Ukraine). He directly influenced the formation of cultural, aesthetic and ideological foundations, which contributed to the development of Ukrainian education, science and literature. O. Konysky considered the establishment of the national language to be one of the ways of nation-building, so his fiction and translations of works from Russian and Polish had not only aesthetic but also Ukrainian-centric goals. Scientific novelty. It has been determined that one of E. Orzeszkowa's novels, translated by O. Konysky, is mistakenly described in contemporary Ukrainian literary criticism not as a translation, but as a work by O. Konysky. Practical significance. The main results of the study can be used in further study of Polish and Ukrainian literary processes of the late $19^{\text {th }}$ - early $20^{\text {th }}$ centuries, as well as in the study of literary and translation activities of O. Konysky.

Key words: translation, short story, national idea, correspondence, small prose.

Олександр Кониський - речник української національної ідеї та інтелектуально-духовного поступу, невтомний борець за незалежність української держави і єдність народу, його право на мову, літературу, власну історію. «Можна любить Україну так, як любив ï̈ Кониський, - але більше як він, - любить не можна» [12, с. 176], - так охарактеризував О. Лотоцький письменника, публіциста, педагога, науковця, адвоката, активного громадського діяча, який усе своє життя лобіював інтереси народу, освітньо-культурне відродження розділеної країни, територіальне, ментальне і світоглядне воз'єднання українців Галичини і Наддніпрянщини. Окрім В. Антоновича, однодумців майже не було, а авторитетний ідейний опонент М. Драгоманов не схвалював палкий націоналізм О. Кониського. Тому надважливим завданням для О. Кониського стало виховання національної еліти, інтелектуального проукраїнського десанту, щоб консолідувати націю: «Прямувати шляхом широкого національного розвитку, національно оздобленого поступу і значить прямувати до всього того, що становить ідеал людського братерства, що становить добробут і щастя людей! Навпаки, іти проти такого націоналізму, іти шляхом космополітизму, значить в ліпшому разі - іти проти поступу, проти щастя людського! Нема до щастя усіх людей іншої реальної путі опріч стежки національного розвитку!» [8, с. 147].

До арешту (1863) та подальшого заслання у Волгоградський край О. Кониський мешкав у Полтаві, де разом з громадівцями надзвичайно плідно займався просвітницькою діяльністю та критикою місцевої влади. Він долучився до створення вечірньої, недільних і суботніх (для євреїв) шкіл, працював «у кожній з них чи то як учитель, чи як бібліотекар, чи розпорядчик» [22, с. 7], написав низку підручників для початкових класів. Через таку активну позицію був ув'язнений. Поширював педагогічні ідеї та відстоював право на навчання українською мовою у статтях і розвідках також після повернення 3 Волгоди (1865).

Національну ідею О. Кониський пропагував безперервно, використовуючи найрізноманітніші платформи (освітню, наукову, публіцистичну, літературну), під пильним наглядом відповідних служб, які намагалися «довести, що „ураинофильство и социализмъ там действенны” $[11$, с. 4]. Слушно зауважив С. Єфремов: «Такими людьми, як Кониський, найбільше держалась українська справа під той темний час, коли навіть голосу 
українського не чутно було; вони були не тільки робітниками, а немов прапорами цілої епохи» [23, с. 427].

О. Кониський - автор духовного гімну України («Боже великий, єдиний...»), автор і дослідник першої грунтовної біографії Т. Шевченка, ініціатор і співзасновник першого українського академічного осередку у Львові - Наукового товариства імені Т. Шевченка - один із талановитих, проте недооцінених українських письменників другої половини XIX століття. На думку С. Єфремова, «Кониський був, мабуть, чи не перший на Україні, що став виступати в письменстві не спорадично, не в часи вільного від службових обов'язків дозвілля, а постійно й систематично, як професіонал» [22, с. 11].

У другій половині XX - поч. XXI століття зацікавлення художнім доробком письменника пожвавилося i, поряд із критичні публікаціями I. Франка [5] й О. Авдиковича [1], почали з'являтися праці, у яких поетичні та прозові твори О. Кониського стали предметом окремих літературознавчих розвідок $[2 ; 3 ; 19]$ чи аналізувались у контексті ширших досліджень, присвячених аналізові художніх явищ другої половини XIX століття [4; 7], на різних рівнях: проблемно-тематичному, поетикальному, стилістичному, генологічному.

Переклади 3 інших мов - це ще один напрям багатогранної діяльності O. Кониського. I хоча його трансляторська практика не була надто активною, порівняно зі сферами, згаданими вище, проте іiі потрібно розглядати як важливий i необхідний елемент формування цілісного образу культури української нації. Переклади відіграють надзвичайно вагому роль у процесі кристалізації будь-якого культурно-естетичного простору. Це наголошував й I. Франко: «Переклади чужомовних творів, чи то літературних, чи то наукових, для кожного народу являються важним культурним чинником, даючи можливість широким народним масам знайомитися 3 творами й працями людського духу, що в інших краях у різних часах причинялися до ширення просвіти та підіймання загального рівня культури» [5, с. 7]. О. Кониський переклав російськомовні твори Т. Шевченка та М. Костомарова, а також дві новели («Великий», «Ані на ступінь») польської письменниці Е. Ожешко.

Україномовні версії творів польської авторки з'явилися у перекладацькій спадщині О. Кониського не випадково. Задовго до перекладу новел «Великий» у 1895 році й «Ані на ступінь» у 1898 році український та польська письменники розпочали епістолярне спілкування ${ }^{1}$, яке тривало протягом 1888 року. Це чотири листи: два польською мовою до О. Кониського і два українською мовою до Е. Ожешко, у яких автори обговорювали непросте становище українського слова, ділилися досвідом літературної праці в умовах жорсткої цензури.

До О. Кониського, як і до І. Франка, з яким Е. Ожешко листувалася у 1886-1888 роках, звернулася першою. Про О. Кониського авторка дізналася від польських письменників, з якими підтримувала тісні контакти. Це Ф. Равіта-

${ }^{1}$ Детальніше про листування Е. Ожешко з О. Кониським див: [18]. 
Гавронський, В. Висоцький та Ч. Нейман, що жили й працювали в Україні та «групувалися навколо „Киевской старины” [21, с. 191]. У листі від 23 червня 1886 року Е. Ожешко згадує про знайомих київських діячів: «Вибачте, що пишу незнаною Вам мовою, але вашою ще не вмію, а іншою не хочу. Крім того, багато людей у Києві говорили, що перекладуть Вам цього листа, якщо буде потрібно» [16, арк. 279]².

Листуючись 3 українськими авторами, польська письменниця усердно працювала над реалізацією плану щодо видання збірника української прози. У листі від 20 березня 1886 року до I. Франка Е. Ожешко резюмувала: «Перший ужиток, який хочу зробити із знайомства 3 українською літературою - це написати обширну студію, а для кращого ознайомлення з нею мого суспільства, долучити до цієї студії переклад одного роману і кілька новел» [13, с. 255]. Ще до епістолярних контактів з українськими колегами польська художниця слова пильно вивчала українську мову, з великою цікавістю студіювала українську літературу і культуру. Для того, щоб досконало та глибоко вивчити мову, побут i традиції нашого народу Е. Ожешко звернулася 3 проханням до І. Франка порадити їй підручники та довідкову літературу з граматики української мови та історії літератури, географії, історії України. І. Франко не лише рекомендував польській авторці матеріали для навчання, а й висилав поштою.

Схожі побажання письменниця адресувала О. Кониському, ділилася з ним думками про видання антології української белетристики наголошуючи: «<...> 3 вашою літературою велика біда. Вона схожа до образу, який щезає. Схопити його дуже важко, бо завжди десь зникає. Знаю про всіх ваших письменників та їхні книжки, але лише одну 3 десяти вдається отримати, бо дев'ять інших пропадає невідомо де» [16, арк. 279]. Отримавши листа від польської письменниці, О. Кониський одразу погодився їй допомагати: «Щоб тілько не треба було Вам, яку звістку, чи що ще з нашого письменства, будьте ласкаві кажіть мені, я все, що спроможуся, зроблю, тай не гадайте, що або турбуєте мене, або що! <..> спробуємо помогти один одному в усьому, що треба, щоб знівечити оті ворожі непорозуміння, якими наділили нас» [10, с. 3]. У другому листі, на прохання Е. Ожешко, О. Кониський уклав скрупульозний перелік «руських прозаїків, котрих треба довести до Антології» [11, с. 2], написавши прізвища українських авторів та їхні твори для польського перекладу.

Епістолярне спілкування Е. Ожешко 3 І. Франком призвело до появи перших україномовних версій творчості польської письменниці. До перекладу малої прози Е. Ожешко долучився й О. Кониський. Щоправда, трансляторська робота над новелою «Великий» здійснювалася не на основі оригінального польського тексту, а з російської версії. «Переклад з манускрипту на мову московську надруковано в I кн. «Русск. Мс.» 18753. 3 відтіля ми й перекладаємо» $[17$, с. 1$]$, - таке пояснення розміщено у кінці першої сторінки перекладу, надрукованого у додатку до «Правди» за 1895 рік. На україно-

\footnotetext{
2 Листи Е. Ожешко до О. Кониського написані польською мовою. Тут і далі переклад з польської наш (I. C.).

3 Дата є помилковою, оскільки російський переклад М. Лаврова був опублікований одночасно 3 польським оригіналом у 1895 році.
} 
мовний варіант «Великого» одразу відреагувала критика, зокрема Л. Васілевський у розвідці «Еліза Ожешкова», опублікованій в часописі «Жите і слово» того ж року, зазначив: «<...> недавно „Правда” почала друкувати переклад однієї повісти Ожешкової, зроблений д. Кониським з великоруської мови. Невже ж з Варшави до Києва дорога через Москву?»[20, с. 46]. Автор статті також відзначив активну трансляторську інтерпретацію белетристики Е. Ожешко німецькою, французькою, чеською й особливо російською: «Там (у Pociї. - I. C.) усі без виємку іiі твори перекладаються зараз по виході в світ оригіналів і то часом кілька разів; вони друкуються в першорядних часописах і окремо коментуються й критикуються» $[20$, с. 46]. Проза Е. Ожешко була надзвичайно популярною в російській літературі, письменниця особисто спілкувалася 3 багатьма перекладачами, а переклади інколи друкувалися одночасно з оригінальними творами. Власне так було з новелою «Великий», яка видавалася трьома мовами у місцевих часописах протягом 1895 року (польською - «Echo Muzyczne, Teatralne i Artystyczne»; російською - «Русская мысль»; українською - додаток до «Правди»).

Психологічна новела «Великий» відрізнялася від попередніх творів Е. Ожешко новими тенденціями, що інтенсивно розвивалися у світовій літературі наприкінці XIX століття як на рівні змісту, так і форми. Відступивши від позитивістських догм, письменниця запропонувала художнє оприявнення влазливої душі скрипаля, його надто пристрасних переживань, інколи психічно неврівноважених станів, які призводили до галюцинацій. Внутрішні монологи героя виписано особливо емоційно, це своєрідні напружені настроєві спалахи, близькі до потоку свідомості.

Типологічно близькою до «Великого» $є$ новела О. Кониського «Музика Павло Дрантусь», яку письменник пропонував Е. Ожешко надрукувати в антології української прози. Гадаємо, що згаданий твір польської авторки зацікавив українського перекладача нестандартною фабулою, глибоким психологізмом та експериментальною поетикою, адже О. Кониський як письменник також еволюціонував «<..> від зразків у річищі етнографічнопобутової течії, реалістичних оповідань до спроб імпресіоністичного письма» $[3$, c. 74].

Окрім «Правди», переклад «Великого» український автор опублікував вдруге, змінивши назву. У III томі [9] чотиритомного видання творів О. Кониського надруковано новелу «Радощі і скорботи великого скрипника», яка $є$ тим самим перекладом. Нижче, під новою назвою, О. Кониський зазначив прізвище авторки твору, використавши скорочення: «П. з П О-вои» [9, с. 184] (Переклад $з$ Пані Ожешкової - I. C.). У листах до Е. Ожешко український письменник звертався, вживаючи слово «пані»: «Шановна Пані Добродійко!», «Високоповажна Пані Добродійко!». 

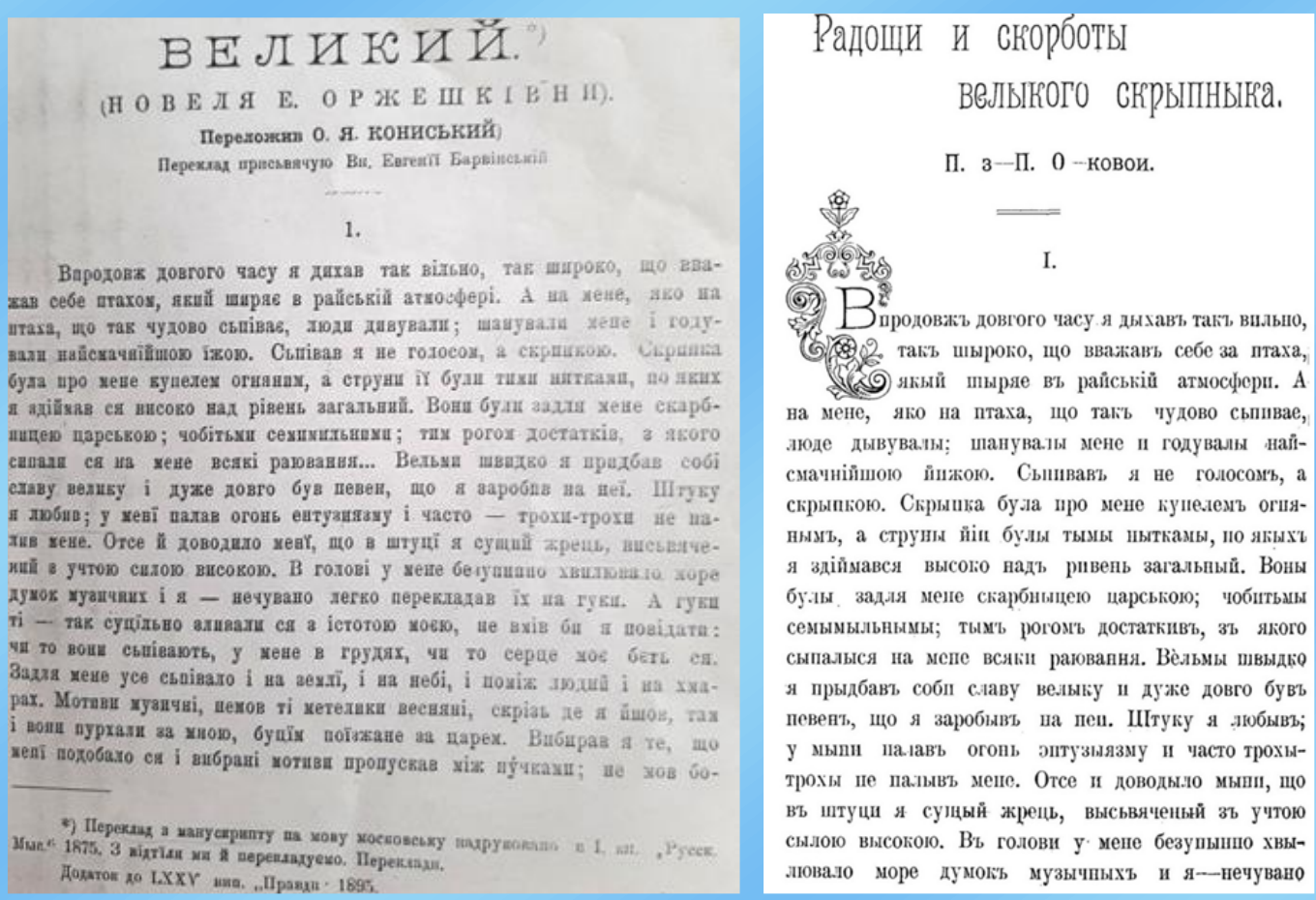

У другій половині XX - на початку XXI віку в працях українських авторитетних літературознавців, які досліджують художні особливості малої прози другої половини ХІХ століття, звернено особливу увагу на твір «Радощі і скорботи великого скрипника» як цікавий зразок новелістики, де реалістичний метод поступово втрачав домінантну позицію на користь «техніки психологічного аналізу <..> підготувавши грунт для психологічної новели початку ХX століття» [4, с. 128]. Автором цієї новели, яку вчені окреслюють як «психологічна студія», де «подано імпресіоністичні малюнки людських галюцинацій - чи то від перевтоми, чи то в хворобливому стані» [4, с. 128] та «лірично-настроєве оповідання» [2, с. 72], названо О. Кониського. Аналізуючи новелістику наддніпрянського прозаїка у контексті нових тенденцій і жанровостильових пошуків на зламі століть, дослідники наголошували, що письменник керувався бажанням «писати в „новій манері”, а отже 3 більшою увагою до психологічного аналізу, до передачі вражень, відчуттів, рефлексій відзначаються такі оповідання Кониського, як ,Зранку до ночі”, „Радощі і скорботи великого скрипника" <..>» [19]; здійснював спроби «писати в „новому стилі”; ідеться про оповідання „Питання”, „Надіï”, „Радощі і скорботи великого скрипника”, „Грішник”, „Черничка” та ін.» [3, с. 77].

Помилкове приписування авторства новели «Радощі і скорботи великого скрипника» О. Кониському жодним чином не впливає на потрактування українського письменника як одного з перших експериментаторів на шляху оновлення змісту і форми в українській новелістиці межі століть: психологізації художнього зображення, екзистенційного осмислення самотності, імпресіоністської образності, увиразнення глибоких внутрішніх переживань, посилення емоційності у внутрішніх монологах, фрагментарності, обірваних речень, ритмізації прози та творення поезії в прозі. Саме до таких творі належать 
«Наймичка», «Хоча була б постаті дожала!», «Хвора душа», «Доля одного письменника», «Музика Павло Дрантусь», «Ранок в Алупці». Натомість слушні думки про те, що текст твору «Радощі і скорботи великого скрипника» це «цікавий передсмертний експеримент в „потоці свідомості” та ритмізованої прози автора-традиціоналіста» [4, с. 128], а також, що до потоку свідомості «звертався навіть такий побутописець, як О. Кониський, зображаючи спалахи галюцинацій („Радощі і скорботи великого скрипника”)» [6, с. 18] потрібно уточнити лише щодо питання авторства. Отже, «Радощі і скорботи великого скрипника» - це переклад новели «Великий» Е. Ожешко, який О. Кониський опублікував вдруге у 1900 році, змінивши назву.

Окрім ілюстративного підтвердження, наведеного вище, ще одним доказом того, що змінена назва «Радощі і скорботи великого скрипника» це переклад О. Кониського новели Е. Ожешко «Великий» є окреслена проблема, яку I. Денисюк сформулював точно і виразно: «співвідношення бацили і генія, величності і мізерності людини, слави і щирості в приязні надають оповіданню «Радощі і скорботи великого скрипника» філософічності» [4, с. 228].

О. Кониським переклав ще один твір Е. Ожешко - новелу «Ані на ступінь» [15], яка була надрукована в часописі «Руслан» 1898 року. Цього ж року українську версію «Ані кусника» [14] опублікував у «Літературнонауковому віснику» О. Маковей. Що ж саме призвело до того, що два варіанти однієї новели були зроблені 1898 року? Звичайно, насамперед треба відштовхуватися від проблемно-тематичного спектра новели, що однаково зацікавила як О. Маковея, так й О. Кониського. Можливо, перекладаючи вищевказаний твір Е. Ожешко, обидва митці не здогадувалися про те, що здійснюють його одночасно. Так, інтерпретація перекладу О. Кониського була зроблена в Києві, а О. Маковея - у Львові.

Маленький хлопчик, герой новели, не може зрозуміти, як багаті й освічені пани не «посідають» своєї землі, не обробляють її й не мають жодного наміру працювати. 3 його грудей виривається велике здивування й водночас жаль до заможних і таких гарних панів: «Таки так, що ні шматочка не маєте, ні на ступінь» (переклад О. Кониського) [15, с. 4]; «Ані шматка, ані кусника?» (переклад О. Маковея) [14, с. 197]. Обидва перекладачі максимально точно відтворюють семантичний і стилістичний рівні оригіналу, проте емоційноекспресивна складова твору яскравіше передана у версії О. Маковея. Більш детальний аналіз перекладів обох авторів у руслі естетичних, художніх, семіотичних особливостей може стати темою окремого дослідження.

Отже, О. Кониський як один з найактивніших адептів національної ідеї другої половини XIX століття своєю багатогранною діяльністю долучився до формування й пропагування культурно-естетичних і світоглядних засад, що сприяли розвиткові української освіти, науки, літератури, самоствердження нації загалом. Одним 3 важливих напрямків націєтворення і відродження держави О. Кониський вважав утвердження національної мови, тому його художня творчість і переклади творів польської письменниці Е. Ожешко мали як естетичні, так україноцентричні цілі. 


\section{ЛІТЕРАТУРА}

1. Авдикович О. Огляд літературної діяльности Олександра Кониського. Звіт дирекції ліиеея Руского Інститута для дівчат в Перемишли. <...> за рік шкільний 1907/1908. Перемишль, 1908. C. 3-24.

2. Бойко Н. До питання дифузних жанрових підвидів малої прози О. Кониського. Лiтературознавчі студіï. 2015. Вип. 43(1). С. 71-78. URL: http://nbuv.gov.ua/UJRN/Lits $2015 \quad 43 \% 281 \% 29 \quad 11$ (дата звернення: 10. 04.2020).

3. Бойко Н. «Таких діячів надто потрібно буває на світанні національного життя...» (літературна спадщина Олександра Кониського). Слово $i$ Час. 2011. № 11. С. 71-80. URL: http://dspace.nbuv.gov.ua/bitstream/handle/123456789/144322/10-Boyko.pdf?sequence=1 (дата звернення: 10. 04.2020).

4. Денисюк I. Розвиток української малої прози XIX - початку XX ст. Львів : Наукововидавниче товариство «Академічний експрес», 1999. 280 с.

5. Франко I. Каменярі. Український текст і польський переклад. Дещо про штуку перекладання. Зібрання творів: у 50. Київ : Наук. думка, 1983. Т. 39. С. 7-20.

6. Франко І. Про жите і діяльність О. Кониського. Львів, 1901. 36 с.

7. Ковалів Ю. У пошуках іманентного сенсу. Історія української літератури: кінець XIX поч. XXI cm. : підручник : y 10 m. Київ : Видавничий центр «Академія», 2013. Т. 2. 624 с.

8. Кониський О. Відчити 3 історії русько-українського письменства. Свim. 1881. № 8-9. С. 11-12, 28-29, 45-147, 67-169, 239-241.

9. Кониський-Перебендя О.Я. Радощі і скорботи великого скрипника: переклад 3 твору Е.Ожешкової. Твори О. Я. Кониського-Перебенді : у 4 m. Ялта, 1900. Т. 3. С. 184-231. URL: http://irbis-nbuv.gov.ua/ulib/item/0001792 (дата звернення: 10.04.2020).

10. Koniski A. List do Elizy Orzeszkowej / w jęz. ukr. AEO 800. 3 s.

11. Koniski A. List do Elizy Orzeszkowej / w jęz. ukr. AEO 800. 6 s.

12. Лотоцький О. Сторінки минулого. Праці укр. наук. Інституту. Варшава, 1932. Т 4. 286 с.

13. Orzeszkowa E. Listy E. Orzeszkowej do I. Franki. Listy : w II t. Warszawa; Grodno : Nakładem Towarzystwa im. Elizy Orzeszkowej, 1938. T. II : Do literatów i ludzi nauki. 1938. Część II. S. 253-280.

14. Ожешко Е. Ані кусника. Чи пам'ятаєш. Новели / пер з пол. О. М. [аковея]. ЛНВ. 1898. T. 2. Кн. 5. С. 189-207.

15. Ожешко Е. Ані на ступінь : Новела / пер з пол. О. Кониського. Руслан. 1898. № 134. С. 4.

16. Ожешко Е. Лист до Кониського О. Я. (польською мовою). ВР ІЛ НАНУ. Ф. 77. № 125. Арк. 279-280.

17. Оржешківна Е. Великий. Новела / пер. 3 пол. О. Я. Кониський. Львів, 1895. 27 с.

18. Спатар I. Слово про Елізу Ожешко, або до проблеми взаємозв'язків Елізи Ожешко 3 українськими письменниками. Вісник Прикарпатського університету. Серія Філологія (Літературознавство). Івано-Франківськ, 2008. Вип. XVII-XVIII. С. 182-187.

19. Сиваченко М. Є. Олександр Кониський. Сатиричні твори URL: https://www.myslenedrevo.com.ua/uk/Lit/K/KonyskyO/Studies/Syvachenko/SatyrychniTvory.html (дата звернення: 10.04.2020).

20. Васілевський Л. Еліза Ожешкова. Житє і слово. 1895. Т. 4. С. 35-46.

21. Вервес Г. Польська література і Україна. Літературно-критичні нариси. Київ : Рад. письменник, 1985. 382 с.

22. Сфремов С. Олександер Кониський. О. Кониський. Вибрані твори в 2 кн. Київ : Видавниче товариство «Час», 1927. Кн.1. С. 5-31. URL: http://shron3.chtyvo.org.ua/Konyskyi/Vybrani_tvory_Knyha_1.pdf (дата звернення: 10.04.2020). 23. Сфремов С. Історія українського письменства. Київ : Femina, 1995. 608 с.

\section{REFERENCES}

1. Avdykovych, O. (1908), “A review of Alexander Konissky's literary activities”, V. Report of the Lyceum Directorate of the Russian Institute for Girls in Przemysl. <...> for the school year 
1907/1908 [“Ohliad literaturnoi diialnosty Oleksandra Konyskoho”, Zvit dyrektsii litseia Ruskoho Instytuta dlia divchat v Peremyshly. <...> za rik shkilnyi 1907/1908], Przemysl, pp. 3-24. (in Ukrainian).

2. Boiko, N. (2015), "On the issue of diffuse genre subspecies of O. Konysky's small prose" ["Do pytannia dyfuznykh zhanrovykh pidvydiv maloi prozy O. Konyskoho"] Literaturoznavchi studii, Issue 43 (1), pp. 71-78, available at: http://nbuv.gov.ua/UJRN/Lits_2015_43\%281\%29_11 (accessed on 10 April 2020) (in Ukrainian).

3. Boiko, N. (2011), "Such figures are needed at the dawn of national life ..." (Alexander Konysky's literary heritage)" ["Takykh diiachiv nadto potribno buvaie na svitanni natsionalnoho zhyttia... (literaturna spadshchyna Oleksandra Konyskoho)"'], Slovo i Chas, No. 11, pp. 71-80, available at: $\quad$ http://dspace.nbuv.gov.ua/bitstream/handle/123456789/144322/10Boyko.pdf?sequence=1 (accessed on 10 April 2020) (in Ukrainian).

4. Denysiuk, I. (1999), The development of Ukrainian small prose of the 19th - beginning of the 20th centuries [Rozvytok ukrainskoi maloi prozy XIX - pochatku XX st.], Naukovo-vydavnyche tovarystvo “Akademichnyi ekspres”, Lviv, 1999, 280 p. (in Ukrainian).

5. Franko, I. (1983), "Kameniari. Ukrainian text and Polish translation. Something about a of translation", Collection of works in 50 volumes. Vol. 39 ["Kameniari. Ukrainskyi tekst i polskyi pereklad. Deshcho pro shtuku perekladannia", Zibrannia tvoriv: u 50 tomakh. T. 39], Nauk. dumka, Kyiv, pp.7-20 (in Ukrainian).

6. Franko, I. (1901), On the Life and Activity of A. Konyssky [Pro zhytie i diialnist O. Konyskoho], Lviv, 36 p. (in Ukrainian).

7. Kovaliv, Yu. (2013), History of Ukrainian literature: the late 19th - the early 20th centuries: textbook in 10 volumes. Vol. 2 [Istoriia ukrainskoi literatury: kinets XIX - poch. XX st.: pidruchnyk u 10 t.], Vydavnychyi tsentr "Akademiia", Kyiv, 2013, 624 p. (in Ukrainian).

8. Konysky, O. (1881), "Fragments from the history of Ruthenian and Ukrainian writing" ["Vidchyty z istorii rusko-ukrainskoho pysmenstva"], Svit, No. 8-9, pp. 11-12, 28-29, 45-147, 67169, 239-241 (in Ukrainian).

9. Konyskyi-Perebendia, O.Ya. (1900), "The joys and sorrows of the great violinist: a translation from the work by E. Orzeszkowa", Works by O.Ya. Konysky-Perebendia in 4 volumes. Vol. 3. ["Radoshchi i skorboty velykoho skrypnyka: pereklad z tvoru E.Ozheshkovoi, Tvory O. Ya. Konyskoho-Perebendi u 4 t. T.3.] Yalta, pp. 184-231, available at: http://irbisnbuv.gov.ua/ulib/item/0001792 (accessed on 10 April 2020) (in Ukrainian).

10. Konysky, O. (1886), Letter to Eliza Orzeszkowa, in Ukrainian [List do Elizy Orzeszkowej, w jęz. ukr.]. AEO 800. 3 p. (in Polish).

11. Konysky, O. (1886), Letter to Eliza Orzeszkowa, in Ukrainian [List do Elizy Orzeszkowej, w jęz. ukr.]. AEO 800. 6 p. (in Polish).

12. Lototskyi, O. (1932), Pages of the past. Works of Ukrainian scientific institute. Vol. 4 [Storinky mynuloho. Pratsi ukr. nauk. Instytutu. T. 4]. Warsaw, 286 p. (in Ukrainian).

13. Orzeszkowa, E. (1938), E. Orzeszkowa's letters to I. Franko. Letters: in 2 vol. Vol. II. Part II [Listy E. Orzeszkowej do I. Franki. Listy: w II t. T. II. Cz. II], Warszawa;Grodno: Nakładem Towarzystwa im. Elizy Orzeszkowej, pp. 253-280. (in Polish).

14. Orzeszkowa, E. (1898), "Not any part. Do you remember. Short stories, trans. by O. Makovei" [“Ani kusnyka. Chy pamiataiesh. Novely: per z pol. O. Makoveia”], LNV, Vol. 2, B. 5, pp. 189-207. (in Ukrainian).

15. Orzeszkowa, E. (1898), "Not a degree: short story”, trans. from Polish by O. Konysky [“Ani na stupin: Novela, per z pol. O. Konyskoho], Ruslan, No. 134, p. 4. (in Ukrainian).

16. Orzeszkowa, E. (1886) Letter to Konysky O. Ya. (in Polish) [Lyst do Konyskoho O.Ya. (polskoiu movoiu)]. F. 77, No. 125, Kyiv, VR IL NANU. Pp. 279-280. (in Ukrainian).

17. Orzeszkowa, E. (1895), Big. Short story, trans. from the Polih by O.Ya. Konysky [Velykyi. Novela, per. z pol. O.Ya. Konyskyi], Lviv, 27 p. (in Ukrainian).

18. Spatar, I. (2008), “A word about Eliza Ozheshko, or about the issue of Eliza Ozheshko's interrelations with Ukrainian writers" ["Slovo pro Elizu Ozheshko, abo do problemy 
vzaiemozv'iazkiv Elizy Ozheshko z ukrainskymy pysmennykamy"], Visnyk Prykarpatskoho universytetu. Seriia Filolohiia (Literaturoznavstvo), Ivano-Frankivsk, Issue XVII-XVIII, p. 182187. (in Ukrainian).

19. Syvachenko, M.Ye. (1990), Oleksandr Konysky. Satirical works [Oleksandr Konyskyi. Satyrychni tvory], available at: https://www.myslenedrevo.com.ua/uk/Lit/K/KonyskyO/Studies/Syvachenko/SatyrychniTvory.html (accessed on 10 April 2020) (in Ukrainian).

20. Vasilevskyi, L. (1895), "Eliza Orzeszkowa" ["Eliza Ozheshkova", Zhyttie i slovo, Vol. 4, pp. 35-46. (in Ukrainian).

21. Verves, H. (1985), Polish literature and Ukraine. Literary-critical essays [Polish Literature and Ukraine. Literary-critical essays], Radianskyi pysmennyk, Kyiv, 382 p. (in Ukrainian).

22. Yefremov, S. (1927), "Oleksander Konysky", A. Konysky. Selected works in 2 books. B. 1 ["Oleksander Konysky", O. Konyskyi. Vybrani tvory v 2 kn. Kn.1.] Vydavnyche tovarystvo "Chas", Kyiv, pp. 5-31. available at: http://shron3.chtyvo.org.ua/Konyskyi/Vybrani_tvory_Knyha_1.pdf (accessed on 10 April 2020) (in Ukrainian).

23. Yefremov, S. (1995), History of Ukrainian Writing [Istoriia ukrainskoho pysmenstva], Femina, Kyiv, 608 p. (in Ukrainian). 